\title{
DNA repair in Mycoplasma gallisepticum
}

\author{
Alexey Y Gorbachev ${ }^{1 * \dagger}$, Gleb Y Fisunov ${ }^{1 \dagger}$, Mark Izraelson ${ }^{1}$, Darya V Evsyutina ${ }^{1}$, Pavel V Mazin ${ }^{1,2}$, Dmitry G Alexeev ${ }^{1,3}$, \\ Olga V Pobeguts ${ }^{1}$, Tatyana N Gorshkova', Sergey I Kovalchuk', Dmitry E Kamashev ${ }^{1}$ and Vadim M Govorun 1,3,4
}

\begin{abstract}
Background: DNA repair is essential for the maintenance of genome stability in all living beings. Genome size as well as the repertoire and abundance of DNA repair components may vary among prokaryotic species. The bacteria of the Mollicutes class feature a small genome size, absence of a cell wall, and a parasitic lifestyle. A small number of genes make Mollicutes a good model for a "minimal cell" concept.

Results: In this work we studied the DNA repair system of Mycoplasma gallisepticum on genomic, transcriptional, and proteomic levels. We detected 18 out of 22 members of the DNA repair system on a protein level. We found that abundance of the respective mRNAs is less than one per cell. We studied transcriptional response of DNA repair genes of M. gallisepticum at stress conditions including heat, osmotic, peroxide stresses, tetracycline and ciprofloxacin treatment, stationary phase and heat stress in stationary phase.

Conclusions: Based on comparative genomic study, we determined that the DNA repair system M. gallisepticum includes a sufficient set of proteins to provide a cell with functional nucleotide and base excision repair and mismatch repair. We identified SOS-response in M. gallisepticum on ciprofloxacin, which is a known SOS-inducer, tetracycline and heat stress in the absence of established regulators. Heat stress was found to be the strongest SOSinducer. We found that upon transition to stationary phase of culture growth transcription of DNA repair genes decreases dramatically. Heat stress does not induce SOS-response in a stationary phase.
\end{abstract}

Keywords: SOS-response, Mycoplasma gallisepticum, DNA repair, Minimal cell, Mollicutes

\section{Background}

Genomic DNA is constantly subject to damage. This includes the misincorporation of nucleotides by DNApolymerases and chemical modification either by endogenous metabolites or external compounds. DNA damage is a frequent event, and cell division is possible because most of the lesions are effectively repaired. The DNA repair mechanisms of bacteria are numerous and universal. The inactivation of single genes in the DNA repair system is generally not lethal because of a significant amount of redundancy among DNA repair pathways [1].

Bacteria of the class Mollicutes features a small though sufficient genome to grow on a cell-free medium and a low GC content (31\% for Mycoplasma gallisepticum). Their genome size typically ranges from 580 thousand to

\footnotetext{
* Correspondence: augorbachev@gmail.com

${ }^{\dagger}$ Equal contributors

${ }^{1}$ Research Institute of Physico-Chemical Medicine, Malaya Pirogovskaya 1a, Moscow 119992, Russian Federation

Full list of author information is available at the end of the article
}

1.4 million bp. Most mollicute species are obligate parasites [2-4]. As a result, they are constantly exposed to stress conditions caused by host defense, including elevated temperature and reactive oxygen species [2]. It is interesting how organisms with reduced genomes retain genome stability under adverse conditions.

DNA repair systems are divided into groups based on mechanism of action. Mismatch repair (MMR) fix nonpairing bases, which originated from the misincorporation of nucleotides by DNA-polymerase [5]. Chemically modified nucleotides are restored by base excision repair (BER). It recognizes specific modifications by dedicated proteins and replaces modified nucleotides with the correct ones [6]. Nucleotide excision repair (NER) deals with a broad spectrum of DNA damage. It removes a section of the defective DNA chain and fills it based on a complementary chain [1]. DNA lesions that are substrate of the BER system can be restored by the NER system but in a less efficient manner [7]. Double strand breaks or crosslinks are removed by homologous recombination. However, this requires information from homologous DNA molecules (not
() Biomed Central

(c) 2013 Gorbachev et al.; licensee BioMed Central Ltd. This is an open access article distributed under the terms of the Creative Commons Attribution License (http://creativecommons.org/licenses/by/2.0), which permits unrestricted use, distribution, and reproduction in any medium, provided the original work is properly cited. 
from a complementary chain, as for BER and NER), which is time consuming and involves massive DNA synthesis $[1,8]$. Therefore, recombination activates as a part of an SOS-response only in cases of severe DNA damage [9]. SOS-response in Mollicutes is of particular interest due to absence of LexA repressor in all Mollicutes [10]. An SOSresponse may involve a number of repair enzymes, but key players are recombination protein and error-prone polymerases [11]. In bacteria, an SOS-response is activated by massive DNA damage [12]. Activation of an SOSresponse inevitably leads to elevation of a mutation rate as well [13], which is unwanted for a cell in normal conditions. Absence of LexA repressor in Mollicutes was considered evidence that an SOS-response is not functional in these bacteria [2,10].

Mismatch repair was considered most degenerated in mycoplasmas. Homologs of MutH, MutS and MutL proteins were not found in all Mollicutes. This led to the conclusion that mutation rate is elevated in mycoplasmas [14]; however, it was later shown that it does not differ from the one in $E$. coli $[15,16]$. It was shown recently that histonelike protein HU (Hup2) in M. gallisepticum is able to recognize mispaired bases in DNA in contrast to $\mathrm{HU}$ from Acholeplasma laidlawii with functional MMR [17,18]. It can also compensate for inactivation of hupAB proteins in E. coli [17]. This may indicate its role in mismatch repair.

In the current study, we attempted to characterize the DNA repair system of Mycopalsma gallisepticum. We identified members of different DNA repair pathways based on genomic data and publications. We quantified mRNA of respective proteins per cell in a set of adverse conditions and identified most of them on the protein level. We showed induction of SOS-response in adverse conditions on a transcriptional level in the absence of a known regulator.

\section{Results}

\section{In silico DNA repair system reconstruction} Nucleotide excision repair

Nucleotide excision repair of $M$. gallisepticum encompasses all required members on the protein level (Tables 1 and 2). This includes UvrA (lesion binding), UvrB (local melt of DNA), UvrC (excision of damaged site), and UvrD-helicase (removal of damaged site), as well as DNA-ligase and DNA-polymerase [19]. The interesting question here is which polymerase is recruited for DNA repair because DNA-polymerase I is absent in M. gallisepticum as well as in most of Mollicutes. It seems that DNA-polymerase III serves both DNA replication and repair. Alternatively, the DNA repair function can be taken by DNA-polymerase IV.

\section{Base excision repair}

Base excision repair starts for glycosylases, which recognize specific lesions in DNA. M. gallisepticum have two en- zymes of this type, including uracil- (Ung) and formamidopyrimidine-DNA-glycosylases (MutM). The next player is AP-endonuclease, which nicks DNA at 5' position from the AP-site. The only AP-endonuclease in Mollicutes is Nfo, which belongs to the endonuclease IV family. This family of endonucleases features $3^{\prime}$-phosphatase activity but lacks $5{ }^{\prime}$-phosphatase and $3^{\prime}-5^{\prime}$ exonuclease activity in contrast to the endonuclease III family [6]. In well-studied bacteria like $E$. coli, the AP-site is removed and repaired by DNA-polymerase I (PolA), which has 5' -3 ' exonuclease activity. In $M$. gallisepticum and most of Mollicutes, this mechanism is likely substituted with DNA-polymerase III and Exo protein, which is an exonuclease, homologous to the $5^{\prime}-3^{\prime}$ exonuclease domain of PolA. Exo seems to originate from PolA as a result of truncation with the loss of the polymerase domain (Figure 1). All components of BER except uracil-glycosylase were identified on the protein level [20-22].

\section{Mismatch repair}

We found two additional proteins that can play a role in mismatch repair. They are MGA_0195 and MGA_0793. The first one contains an endonuclease domain that belongs to the same superfamily as the endonuclease domain of MutH. The second one contains a vsr domain, which takes part in the repair of mispaired guanines. MGA_0195 and MGA_0793 were identified on the protein level (Table 2). A hallmark of M. gallisepticum is the absence of known exonucleases (Exo I, Exo VII, Rec), Exo X [5]) of the MMR pathway. However, missing activity can be compensated by exonuclease Exo, a truncated PolA.

We identified one DNA methylation enzyme: HsdM. This is site-specific methylase that methylate adenine in position six.

\section{Recombinational repair system}

The genome of $M$. gallisepticum carries genes that encode key proteins required for recombination - recombinase RecA, RecR, and RecO (MGA_0016), as well as genes $\operatorname{ruv} A$ and $\operatorname{ruvB}$, encoding a DNA helicase RuvAB (involved in the migration of the DNA chains), as well as two genes encoding enzymes that allow Holliday junction resolution - DNA resolvase $\operatorname{RecU}$ and MGA_0836. In addition, there is a gene $s m c$, encoding Smc-cohesin capable of implementing cohesion after the replication of chromosomes, thus participating in the recombinational repair [23].

\section{SOS response system}

The following participants of SOS-system were found in the genome of $M$. gallisepticum: recombinase A $(\operatorname{rec} A)$, recombinase $\mathrm{R}$ (recR), helicase complex $(\operatorname{ruv} A, \operatorname{ruv} B)$, nuclease-helicase complex UvrABC, and DNA-dependent 
Table 1 Probable participants of the DNA repair system in $M$. gallisepticum

\begin{tabular}{|c|c|c|c|c|c|}
\hline $\begin{array}{l}\text { DNA repair } \\
\text { system }\end{array}$ & Gene name & Function & $\begin{array}{l}\text { Presence in genome } \\
\text { M. gallisepticum }\end{array}$ & $\begin{array}{l}\text { Copy number of mRNA } \\
\text { per one genome }\end{array}$ & $\begin{array}{l}\text { Presence in } \\
\text { proteome }\end{array}$ \\
\hline All systems & $\operatorname{lig} A$ & DNA ligase & + & 0.03 & + \\
\hline $\begin{array}{l}\text { DNA } \\
\text { methylation }\end{array}$ & hsdM & DNA-methyltransferase & + & nd & - \\
\hline MMR & Exo & 5'- 3'-exonuclease & + & nd & + \\
\hline MMR & hup2 & DNA-mismatch binding & + & 0.4 & + \\
\hline MMR & MGA_0793 & Putative vsr protein & + & nd & + \\
\hline MMR & MGA_0195 & Putative MutH analogue & + & nd & + \\
\hline NER and SOS & uvrA & Excinuclease $A B C$ subunit $A$ & + & 0.02 & + \\
\hline NER and SOS & $u v r B$ & Excinuclease $A B C$ subunit $B$ & + & 0.02 & + \\
\hline NER and SOS & uvrC & Excinuclease $A B C$ subunit $C$ & + & 0.02 & + \\
\hline NER and MMR & uvrD & DNA helicase II & + & 0.04 & + \\
\hline BER & fpg (mutM) & Formamidopyrimidine-DNA glycosylase & + & 0.09 & + \\
\hline BER & Ung & Uracil-DNA glycosylase & + & 0.01 & - \\
\hline BER & Nfo & endonuclease IV & + & 0.08 & + \\
\hline $\begin{array}{l}\text { Recombination } \\
\text { and SOS }\end{array}$ & recA & Recombinase RecA & + & 0.01 & + \\
\hline $\begin{array}{l}\text { Recombination } \\
\text { and SOS }\end{array}$ & ruvA & $\begin{array}{l}\text { Holliday junction ATP-dependent DNA } \\
\text { helicase subunit A }\end{array}$ & + & 0.01 & - \\
\hline $\begin{array}{l}\text { Recombination } \\
\text { and SOS }\end{array}$ & ruv $B$ & $\begin{array}{l}\text { Holliday junction ATP-dependent DNA } \\
\text { helicase subunit B }\end{array}$ & + & 0.01 & - \\
\hline Recombination & Smc & Chromosome cohesion & + & nd & + \\
\hline $\begin{array}{l}\text { Recombination } \\
\text { and SOS }\end{array}$ & reck & Recombination protein $\operatorname{Rec} R$ & + & 0.02 & + \\
\hline Recombination & MGA_0016 & Recombination protein $\mathrm{RecO}$ & + & nd & - \\
\hline Recombination & recU & Holliday junction resolvase & + & nd & - \\
\hline Recombination & MGA_0836 & Holliday junction resolvase & + & nd & + \\
\hline sos & $\operatorname{din} B$ & DNA-polymerase IV & + & 0.01 & + \\
\hline
\end{tabular}

nd - no data; "_" - not detected.

DNA polymerase IV $(\operatorname{din} B)$ which homologous to the mutagenic DNA pol IV of E. coli. In bacteria, this polymerase (along with DNA polymerase V, which is absent in all members of the class Mollicutes) is able to use damaged DNA template [24]. At the same time, we didn't find any homologs of known regulators of the bacterial SOSsystem (LexA [25], HdiR [26]) in any of the analyzed genomes of Mollicutes. We found all of the prospective members of the SOS-response system at the mRNA level; while at the protein level, we were unable to identify only helicase RuvAB (Table 2).

\section{Presence of DNA-repair transcripts in the cell}

Comparative analysis based only on genomic data does not allow us to draw conclusions about genes expression and the functional activity of the proteins encoded by them. To test the activity of the annotated genes, we carried out a quantitative analysis of transcription levels for the genes of the repair system by quantitative reverse transcription PCR (droplet-digital PCR and real-time PCR - see Methods). We also counted the number of transcripts copies per single bacterial genome. The results of the expression assay for the studied genes at the mRNA and protein levels are shown in Table 1. Transcription was detected for all of analyzed genes.

It should be noted that the number of copies of mRNA varies from one per one hundred (recA, ruvA, ung, $\operatorname{din} B$ ) to one per 2.5 copies of genomic DNA (hup2). If we assume that each cell contains, on average, one copy of genomic DNA, the presence of transcripts is rather low, and in most of the cells there are no transcripts of the genes' encoding repair system proteins.

\section{Presence of DNA-repair proteins in the cell}

In order to assess the presence of repair systems members at the protein level, we used the methods of liquid 
Table 2 DNA repair proteins identification by LC-MS/MS

\begin{tabular}{|c|c|c|c|c|c|}
\hline NCBI ID & Protein name & $\begin{array}{l}\text { Unused } \\
\text { score* }\end{array}$ & $\begin{array}{l}\text { ProteinPilot } \\
\text { score }\end{array}$ & $\begin{array}{l}\text { The number of unique peptides } \\
\text { (with the reliability of } \\
\text { identification }>=95 \% \text { ) }\end{array}$ & $\begin{array}{l}\text { Coverage protein sequence by unique } \\
\text { peptides (with the reliability of } \\
\text { identification }>=95 \% \text { ) }\end{array}$ \\
\hline gi|31541218 & SMC (Cohesin) & 84.01 & 84.01 & 55 & 54.43 \\
\hline gi|284811881 & $\begin{array}{l}\text { UvrA (Excinuclease } \\
\text { ABC subunit } B \text { ) }\end{array}$ & 75.8 & 75.8 & 50 & 55.67 \\
\hline gi|284811888 & $\begin{array}{l}\text { MGA_0793 (DNA } \\
\text { helicase, contain } \\
\text { vsr-domain) }\end{array}$ & 62.07 & 62.07 & 41 & 36.41 \\
\hline gi|284812070 & UvrD (DNA helicase II) & 51.65 & 51.65 & 27 & 47.54 \\
\hline gi|284811857 & $\begin{array}{l}\text { UvrB (Excinuclease ABC } \\
\text { subunit B) }\end{array}$ & 41.75 & 41.75 & 24 & 39.01 \\
\hline gi|31541419 & Nfo (endonuclease IV) & 31.18 & 31.18 & 17 & 63.04 \\
\hline gi|284812280 & LigA (DNA ligase) & 24.41 & 24.83 & 13 & 23.08 \\
\hline gi|284812220 & $\begin{array}{l}\text { RecR (recombinase } \\
\text { RecR) }\end{array}$ & 24.06 & 24.06 & 15 & 72.82 \\
\hline gi|284811982 & $\begin{array}{l}\text { MutM } \\
\text { (Formamidopyrimidine- } \\
\text { DNA glycosylase) }\end{array}$ & 20.02 & 20.02 & 10 & 41.97 \\
\hline gi|31541551 & $\begin{array}{l}\text { MGA_0195 (contain } \\
\text { endonuclease type II } \\
\text { domain) }\end{array}$ & 18.9 & 18.9 & 18 & 49.18 \\
\hline gi|284812101 & $\begin{array}{l}\text { Hup2 (histone-like } \\
\text { protein) }\end{array}$ & 16.7 & 18.1 & 23 & 71.72 \\
\hline gi|284811981 & Exo (5'- 3'-exonuclease) & 12.01 & 12.01 & 8 & 37.85 \\
\hline gi|284812049 & $\begin{array}{l}\text { UvrC (Excinuclease ABC } \\
\text { subunit C) }\end{array}$ & 6.19 & 6.19 & 4 & 5.672 \\
\hline gi|31541441 & $\begin{array}{l}\text { MGA_0016 } \\
\text { (recombinase RecO) }\end{array}$ & 5.29 & 5.29 & 3 & 19.5 \\
\hline gi|31541171 & $\begin{array}{l}\text { putative Holliday } \\
\text { junction resolvase }\end{array}$ & 4.9 & 4.9 & 5 & 31.69 \\
\hline gi|284812207 & $\begin{array}{l}\text { DinB (DNA-polymerase } \\
\text { IV) }\end{array}$ & 4.05 & 4.05 & 2 & 5.985 \\
\hline gi|31541522 & $\begin{array}{l}\text { RecA (recombinase } \\
\operatorname{Rec} A)\end{array}$ & 4.01 & 4.01 & 2 & 8.547 \\
\hline gi|31541659 & $\begin{array}{l}\text { Ung (Uracil-DNA } \\
\text { glycosylase) }\end{array}$ & 3.13 & 3.86 & 3 & 13.85 \\
\hline
\end{tabular}

*The protein identification algorithm receives the value score for the protein as the sum of the scores for all its related peptides (the score in the program is a direct derivative of ProteinPilot reliability of identification). In the case where a peptide is common to the two proteins, its contribution to the score of the protein, which has a lower accuracy of the identification (less than the total score) will be less than the maximum possible value, calculated based on the reliability of his identification. Thus, the value of the unused score reflects the use of the same peptides (or rather the spectrum on the basis of which were identified peptides) in the identification of other proteins. The closer the value of the unused score to the total score of the protein, the more specific and accurate is this identification.

chromatography-mass spectrometry for the comprehensive identification of all the proteins in the cells of $M$. gallisepticum. We have identified 561 proteins in total (data not shown) by using the following selection criteria: the number of unique peptides for protein - at least two - and a global FDR of 1\% (based on the analysis in PSPEP, with threshold unused score for the protein equaled 0.4 ). Thus 17,221 unique peptides have been identified (global FDR 1\% PSPEP). It should be noted that due to the fact that the algorithm Paragon, used for searching, works on the basis of probability factors, the total number of peptides includes not only non-modified tryptic peptides but semi-tryptic and non-tryptic peptides as well, and peptides containing all possible amino acid modifications considered in the default search algorithm of Paragon.

Analysis of the presence of the DNA repair proteins (Table 2) showed the presence of most of them in the mycoplasma's proteome - 18 proteins for 22 genes are listed in Table 2. All proteins in Table 2 were unique according to the groups of spectrums using the Pro Group algorithm. 


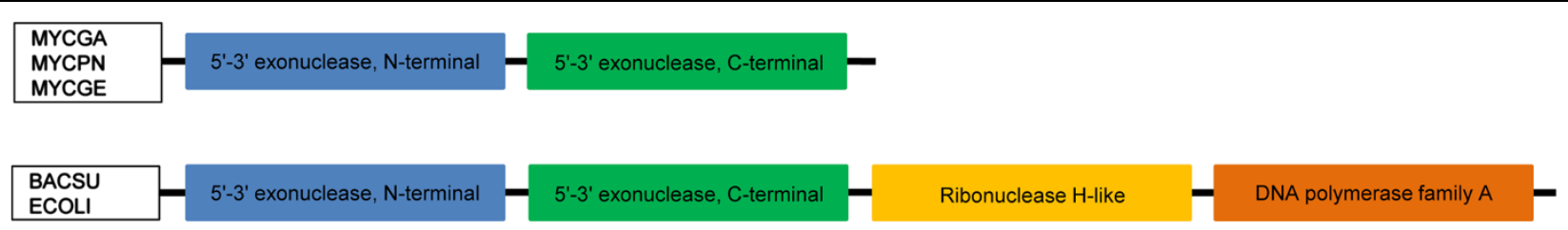

Figure 1 Domain organization of Exo protein of $M$. gallisepticum, M. genitalium, and M. pneumoniae in comparison to DNA polymerase I of $E$. coli and B. subtilis.

\section{Repair system genes response on stress $\left(\mathrm{T}, \mathrm{NaCl}, \mathrm{H}_{2} \mathrm{O}_{2}\right.$,} stationary phase of growth, antibiotics)

According to the literature data, the SOS-repair system of Mollicutes have undergone reduction [10]. In order to understand whether an SOS-response takes place in $M$. gallisepticum, we decided to test changes in the levels of mRNAs of the genes' encoding proteins of the repair system in response to stress influences. We exposed the cells to sub-lethal stress (see Methods) - temperature, osmotic and peroxide stress, and antibiotics. Such effects were selected because they are physiologically common for parasites, as the interaction with the host organism cells encounter reactions of inflammation: heat, immune system peroxide attack, and antibiotics treatment. Figure 2A shows the color map, representing the change of the transcription profiles for the genes' encoding DNA repair proteins. Raw data are presented in Additional file 1.

Ciprofloxacin is known as an SOS-inducer in different bacteria [13,27]. It was used as a reference condition to identify members of SOS-response in M. gallisepticum. Ciprofloxacin treatment resulted in the upregulation of $\operatorname{rec} A, \operatorname{rec} R, u n g, \operatorname{ruv} A$, $\operatorname{lig} A, \operatorname{par} C$, and $\operatorname{din} B$. Remarkably, the 15 -fold induction of error-prone polymerase $(\operatorname{din} B)$ was the strongest effect of the ciprofloxacin treatment. Tetracycline treatment induced upregulation of the SOS-response participants $\operatorname{rec} A$ and $\operatorname{rec} R$ but not $\operatorname{din} B$. DNA gyrase (gyrA and gyrB), which is a target of ciprofloxacin, was induced by tetracycline but not ciprofloxacin. Osmotic stress induced the upregulation of $\operatorname{din} B$ and $u n g$ but not recA and recR. Peroxide stress had little effect on the transcription of genes involved in DNA repair. Heat stress invoked the strongest response among all types of stress. Response to heat stess includes genes involved in responses to ciprofloxacin, $u v r A B C D, n f o$ glycosylase, and DNA gyrase ( $g y r A$ and $g y r B)$. It may be concluded that the stress response system of $M$. gallisepticum consists of several regulons.

The stationary growth phase differs remarkably from the exponential phase in terms of gene expression as well as stress response. The stationary phase demonstrates a significant downregulation of most of the studied genes. Heat stress in the stationary phase did not result in the change of expression of any studied gene in contrast to its exponential phase. It may indicate that the transcription process in the stationary phase is modulated by some global regulator, like an alternative sigma factor.

The transcription profile for the repair system genes in M. gallisepticum under heat shock conditions (Figure 2B) suggests three groups of genes. The first group is characterized by a gradual growth of the transcription level and includes the majority of the genes. The second group includes the genes that respond to the heat stress by dramatical increasing of the transcription level following by decreasing or stagnation of the last one. The third group includes two genes of histone-like proteins hup1 and hup2. They are characterized by a steady decline of transcription (Figure 2B).

\section{Discussion}

The study of the mycoplasma repair system, as bacteria with a reduced genome, gives an indication of the minimum number of genes required to maintain genomic stability. Comparative analysis shows that the repair system of M. gallisepticum includes fewer genes than the one of E. coli. However, if we give preference to functional rather than numerical parameters, we can see the presence of the key elements of all major repair systems in the absence of overlapping units.

The results show that the possible composition of the M. gallisepticum repair system may be greater than it was assumed up until now. In particular, we found several previously unknown mycoplasma proteins. One of them - a protein MGA_0793 - was annotated as a hypothetical protein of unknown function. Results of the alignment revealed homology with the Vsr protein, which was involved in the mismatch repair of DNA containing an unpaired guanine in E. coli [28]. Interestingly, the HU (Hup2) protein identified earlier in $M$. gallisepticum, capable of binding DNA mismatches, does not bind unpaired T-G, A-G, and G-G base pairs [17]. The Figure 3 shows a hypothetical model of the MMR system in $M$. gallisepticum.

We identified one DNA methylation enzyme: HsdM. This is site-specific methylase that methylate adenine in position six. DNA methylation is required for MMR pathways to distinguish the correct strand to use as a template [5]. It was shown that methylation occurs in 


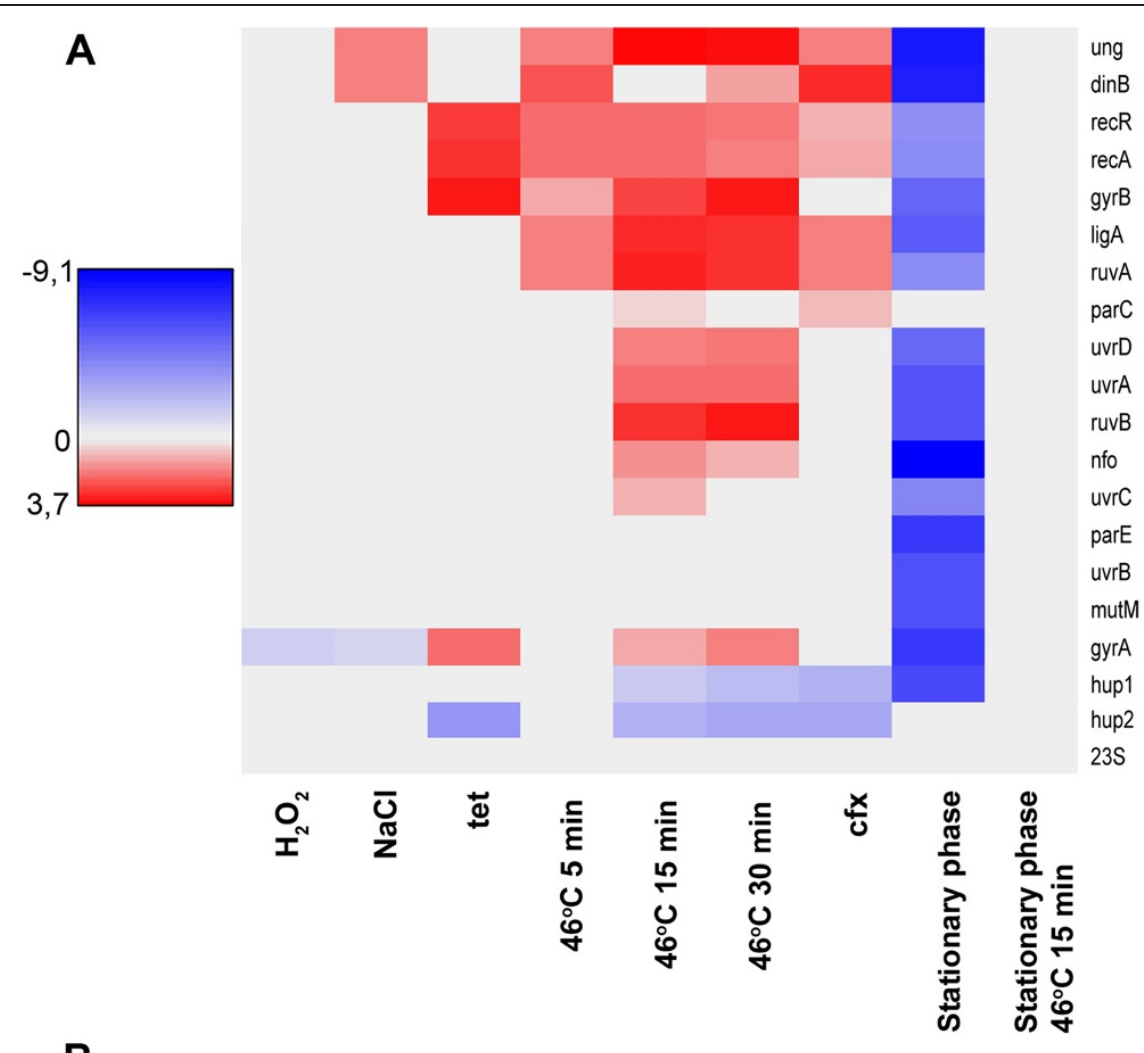

B
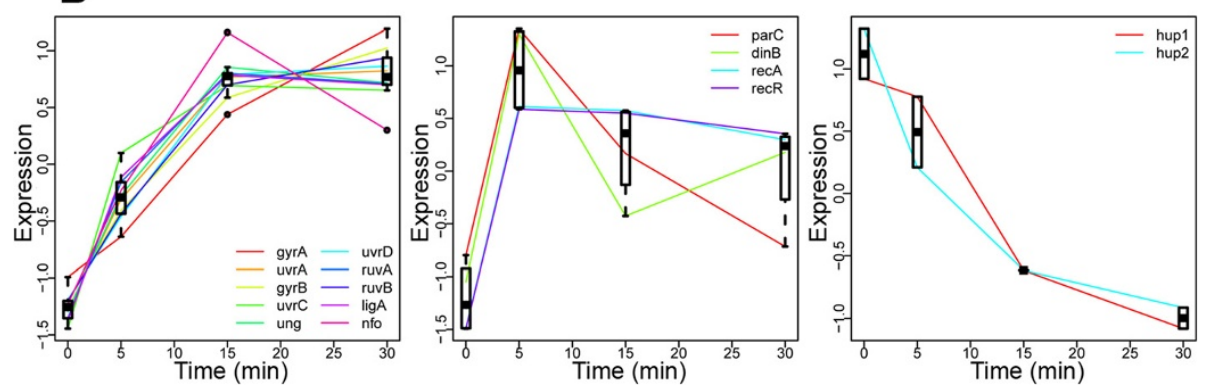

Figure 2 Transcription of genes of $\boldsymbol{M}$. gallisepticum involved in DNA repair and homeostasis. A - Transcription profiles of DNA repair and homeostasis genes under different conditions. 23S rRNA gene was used as a reference. Genes with q-values less than 0.05 were considered to change the expression significantly. Colors indicate direction (red for upregulation, blue for downregulation) and level of expression change ( $\log 2)$. Gray indicates no statistically significant change in expression (t-test, $\mathrm{BH}$-correction, q-value $>0.05$ ); tet - tetracycline treatment, $\mathrm{cfx}-$ ciprofloxacin treatment. $\mathbf{B}$ - Kinetics of the transcriptional response during heat stress. Each box shows a different expression pattern (see Methods). Individual genes are shown by lines. Only genes that significantly change expression with at least one stress duration are shown. Gene expressions were normalized to mean zero and variance one before plotting. Distributions of normalized expressions for given stress duration and pattern are shown by boxes. Genes with the same rank in all conditions were considered to have similar expression patterns. Only genes with significant expression changes between control and at least one stress duration were used.

mycoplasmas [29-31]. However dam-methyltransferase required for the methylation of GATC sites is absent in M. gallisepticum, the discrimination of the chains may be due to the interaction of the repair complex with the B-subunit of DNA polymerase III in replication - such a mechanism was previously shown for a number of microorganisms (Gram-positive bacteria) [1]. Thus we can at least say that $M$. gallisepticum has an enzyme capable of recognizing and binding DNA mismatches, as well as an enzyme hypothetically capable of the excision of the damaged DNA fragment. But the question remains, which enzyme of mycoplasma is a functional analog of MutH protein, which is required to make a single-strand break in the DNA being repaired.

We found that $M$. gallisepticum has the full pathway of nucleotide excision repair and recombination 


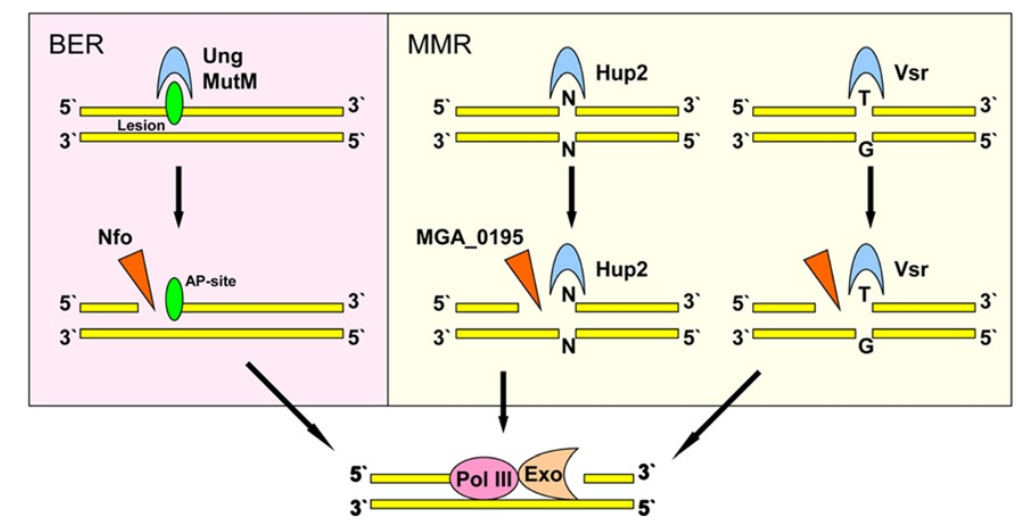

Figure 3 Hypothetical model of the MMR and BER systems in M. gallisepticum.

of DNA. From all of DNA recombination participants, only RecR have been previously found in Mycoplasma gallisepticum at the protein level [20-22]. In this study, we identified RecA and Smc proteins as well (Table 2).

Of particular interest for the analysis of gene excision is the base excision repair system, as it has always been represented by a large number of proteins, each of which recognizes a different type of damage. There are three known types of damage: oxidation, alkylation, and deamination. DNA glycosylase MutM in E. coli, whose homolog is present in the genome of M. gallisepticum, corrects the most frequently occurring DNA damage caused by endogenous oxidative stress [32]. Uracil-glycosylase removes uracil, which arises spontaneously by the deamination of cytosine or by erroneous inclusion during replication. Mollicutes have only one of two AP-endonucleases - endonuclease IV. It's interesting that endonuclease IV (Nfo) has an additional activity - it recognizes oxidized bases (hydroxycytosine, dihydroxyuracil, and dihydroxythymine) and makes a single-stranded gap upstream of the damage, which is used as a primer for the repair by polymerase and ligase [7]. The Figure 3 shows a hypothetical model of the BER system in M. gallisepticum.

Assuming that Mollicutes are bacteria with a minimal genome and are capable of self-reproduction, we come to the conclusion that they possess the number of repair system proteins that are necessary and sufficient for life in the cell-free medium.

The results of the gene transcription assay indicate that the mRNA molecules are not present in every cell in the population (see Table 1). These data are consistent with the literature and may be associated with the long lifetime of the functional protein in contrast to the mRNA [33]. At the proteomic level, we were able to identify a large portion $(80 \%)$ of repair proteins, including $\mathrm{Din} B$ and RecA, members of SOS-response, which is an additional indication of the functionality of the repair system in $M$. gallisepticum.

An interesting result of the transcription-profiling assay was the induction of SOS-response genes in different shocks. This fact interested us for several reasons. First of all, such a response has not been shown previously in Mollicutes, including large-scale studies of transcription responses in M. pneumoniae [34], which is one of the closest relatives of $M$. gallisepticum according to phylogenetic studies [35]. The other interest is that the genomes of all members of the class Mollicutes don't have any known regulator of the SOS-response system, and therefore several authors consider the SOS-system as non-functional in mycoplasmas $[2,10]$. However, our results are consistent with published data obtained by the transcriptional analysis of non-relatives to mycoplasmas bacteria, where the regulatory system of the SOSresponse was described $[1,36,37]$. These observations may indicate the functionality of the SOS-response on the one hand and the presence of an unknown regulator on the other. In favor of the hypothesis of the presence of such a regulator, this may also indicate the presence of a number of genes in the genome, whose protein products, according to the annotation, have sequence-specific DNA-binding domains and could potentially act as transcription factors (data not shown). In addition rapid induction at the level of gene transcription in the second group (Figure 2B) may be indicative of the presence of a repressor that acts similar to the previously described LexArepressor in the $E$. coli. The subsequent decline of the mRNA of parC and $\operatorname{din} B$ genes may be due to the presence of a negative feedback regulation. This is particularly likely in the case of $\operatorname{din} B$, which encodes an alternative DNA polymerase as its activation can lead to dangerously high levels of mutagenesis. The increase in mRNA levels of most of the repair system 
genes may be a consequence of the global regulatory mechanism rather than the result of a single transcription factor.

Demonstrated here, the induction of DNA polymerase IV in different types of stress is consistent with the literature and may be a mechanism of adaptation to stress by increasing endogenous levels of mutagenesis $[9,13,38,39]$.

\section{Conclusions}

Based on comparative genomic study, we determined that the DNA repair system $M$. gallisepticum includes a sufficient set of proteins to provide a cell with functional nucleotide and base excision repair and mismatch repair. We identified SOS-response in M. gallisepticum on ciprofloxacin, which is a known SOS-inducer, tetracycline and heat stress in the absence of established regulators. Heat stress was found to be the strongest SOS-inducer. We found that upon transition to stationary phase of culture growth transcription of DNA repair genes decreases dramatically. Heat stress does not unduce SOSresponse in a stationary phase.

\section{Methods}

\section{Strains and conditions}

Mycoplasma gallisepticum S6 was cultivated on a liquid medium [40] at $37^{\circ} \mathrm{C}$ for 12 and 24 hours for exponential and stationary phases, respectively (Additional file 2). Cells were passaged twice for 24 hours, starting from frozen culture prior to the experiment. Cells were passaged in 1:10 dilution. Cells were harvested by centrifugation at $8000 \mathrm{~g}$ and $4^{\circ} \mathrm{C}$ for $10 \mathrm{~min}$.

\section{DNA extraction}

Cells were harvested as described above and lysed with CTAB buffer (2\% CTAB, $100 \mathrm{mM}$ Tris- $\mathrm{HCl}, \mathrm{pH}=8.0$, $20 \mathrm{mM}$ EDTA, $1.4 \mathrm{M} \mathrm{NaCl}$ ) at $60^{\circ} \mathrm{C}$ for $30 \mathrm{~min}$ with subsequent chloroform extraction (1:1) and isopropanol precipitation (1:1) with the addition of $10 \% \mathrm{v} / \mathrm{v}$ sodium acetate [41].

\section{RNA extraction and CDNA synthesis}

Total RNA was extracted directly from the cell culture using TrizolLS (Invitrogen) reagent (1:3 cell culture: TrizolLS) with subsequent chloroform extraction (1:5 chloroform: TrizolLS) and isopropanol precipitation (1:1). RNA was treated by DNase I (Thermo Scientific) and used for cDNA synthesis with $\mathrm{H}$-minus Mu-MLV reverse transcriptase (Thermo Scientific).

\section{Real-time PCR and droplet-digital PCR}

Real-time PCR was performed using iQ SYBR Green Supermix (Bio-Rad) and CFX96 ${ }^{\text {ma }}$ Real-Time PCR Detection System (Bio-Rad) PCR machine. Droplet digital PCR allows direct quantification of DNA molecules in a sample [42]. It was performed using $\mathrm{ddPCR}^{\text {mi }}$ Supermix for Probes (Bio-Rad) and QX100 system (droplet generator and droplet reader) along with a DNA Engine Tetrad 2 (Bio-Rad) PCR machine. Real-time and ddPCR data was analyzed with CFX Manager and QuantaSoft (Bio-Rad) software, respectively. Primers and probes are listed in Additional file 3. All PCR experiments were carried out in three biological and two technical replicates.

\section{Quantification of RNA copy number per cell}

The copy number of RNA and DNA molecules was measured using ddPCR. Final data was normalized with the respect of cell culture volume which results in a copy number of RNA and DNA per unit of culture volume. The copy number of RNA per cell was estimated as a ratio of RNA per DNA copy number based on the assumption that cells have one copy of genomic DNA.

\section{Determination of sub-lethal conditions}

Sub-lethal conditions were determined as conditions when stressful conditions are maximal but most of the cells are still viable. Working under such conditions ensures the maximal response in the absence of massive cell death, which can significantly affect results. Cell viability was estimated by the determination of colony forming units that are formed by cells after stress. Sublethal conditions for different stresses were found to be the following: $46^{\circ} \mathrm{C}$ for 1 hour for heat stress, $1.2 \mathrm{M}$ $\mathrm{NaCl}$ for 1 hour, $0.02 \% \mathrm{H}_{2} \mathrm{O}_{2}$ for 1 hour, $2 \mu \mathrm{g}$ of ciprofloxacin for 4 hours, and $8 \mu \mathrm{g}$ of tetracycline for 1 hour.

\section{Protein extraction and 1D electrophoresis}

Cells harvested as described were washed twice in a wash buffer $(150 \mathrm{mM} \mathrm{NaCl}, 50 \mathrm{mM}$ Tris- $\mathrm{HCl}, 2 \mathrm{mM}$ $\mathrm{MgCl}_{2}, \mathrm{pH}=7.4$ ). Cells were lysed in $20 \mu \mathrm{l}$ of $1 \%$ SDS in $100 \mathrm{mM} \mathrm{NH}_{4} \mathrm{HCO}_{3}$ and incubated in an ultrasonic bath for $15 \mathrm{~min}$ with subsequent centrifugation at $10000 \mathrm{~g}$ at $4^{\circ} \mathrm{C}$ for $5 \mathrm{~min}$. Supernatant was taken, and protein concentration was determined by Bicinchoninic acid protein assay kit (Sigma). $20 \mu \mathrm{l}$ of $2 \mathrm{x}$ Laemmli reagents were then added, and samples were incubated at $95^{\circ} \mathrm{C}$ for $5 \mathrm{~min}$. Then $50 \mu \mathrm{g}$ of protein was loaded to polyacrylamide gel $(10 \times 0.1 \mathrm{~cm}, 12 \%$ polyacrylamide $)$, and electrophoresis was performed according to Laemmli [43] (10 mA current). Electrophoresis was stopped when the front dye reached $1.5 \mathrm{~cm}$ in separating gel.

\section{Trypsinolysis in polyacrylamide gel}

The polyacrylamide gel was fixed in a fixation buffer (20\% $\mathrm{CH}_{3} \mathrm{OH}$ and $10 \% \mathrm{CH}_{3} \mathrm{COOH}$ ) for $30 \mathrm{~min}$ and washed twice in $\mathrm{H}_{2} 0$. The gel was cut in pieces $1 \times 1 \mathrm{~mm}$, transferred into tubes, and treated with $10 \mathrm{mM}$ DTT and $100 \mathrm{mM} \mathrm{NH}_{4} \mathrm{HCO}_{3}$ for $30 \mathrm{~min}$ at $56^{\circ} \mathrm{C}$. Then proteins were alkylated with $55 \mathrm{mM}$ iodoacetamide in 
$100 \mathrm{mM} \mathrm{NH}_{4} \mathrm{HCO}_{3}$ for $20 \mathrm{~min}$ in the dark. Then water was removed from gel pieces by the addition of $100 \%$ acetonitrile.

Dehydrated samples were treated with a $150 \mu$ trypsin solution $\left(40 \mathrm{mM} \mathrm{NH}_{4} \mathrm{HCO}_{3}, 10 \%\right.$ acetonitrile, $20 \mathrm{ng} / \mu \mathrm{l}$ Trypsin Gold, mass spectrometry grade, Promega). Samples were incubated for $60 \mathrm{~min}$ at $40^{\circ} \mathrm{C}$ and for $16-18 \mathrm{~h}$. at $37^{\circ} \mathrm{C}$. Peptides were extracted one time by $5 \%$ formic acid and two times by $50 \%$ acetonitrile with $5 \%$ formic acid. Extracts were joined and dried on a vacuum centrifuge at $45^{\circ} \mathrm{C}$. Precipitate was diluted in $50 \mu \mathrm{l}$ of $5 \%$ acetonitrile with $0.1 \%$ formic acid.

\section{Chromato-mass-spectrometry}

Peptides were analyzed using a TripleTOF 5600+ (ABSciex) mass-spectrometer with NanoSpray III ion source and NanoLC Ultra 2D + chromatograph (Eksigent). Chromatographic separation was carried out in the gradient of acetonitrile in water (5 to $40 \%$ of acetonitrile in $120 \mathrm{~min}$ ) with $0.1 \%$ formic acid on $75 \times 150 \mu \mathrm{m}$ columns with Phenomenex Luna C18 $3 \mu \mathrm{m}$ sorbent and a flow rate of $300 \mathrm{~nL} / \mathrm{min}$.

The IDA mode of a mass-spectrometer was used to analyze peptides. Based on the first MS1 spectrum (mass range for analysis and subsequent ion selection for MS2 analysis was $300-1250 \mathrm{~m} / \mathrm{z}$, signal accumulation was $250 \mathrm{~ms}$ ), 50 parent ions with maximum intensity in the current spectrum were chosen for subsequent MS/MS analysis (resolution of quadrupole UNIT was $0.7 \mathrm{Da}$, measurement mass range was $200-1800 \mathrm{~m} / \mathrm{z}$, optimization of ion beam focus was to obtain maximal sensitivity, signal accumulation was $50 \mathrm{~ms}$ for each parent ion). Nitrogen was used for collision dissociation with fixed average energy of $40 \mathrm{~V}$. Collision energy was linearly increased from 25 to $55 \mathrm{~V}$ during signal accumulation time $(50 \mathrm{~ms})$. Parental ions that had already been analyzed were excluded from analysis for $15 \mathrm{sec}$.

\section{Analysis of mass-spectrometry data}

Raw data was analyzed with ProteinPilot 4.5 revision 1656 (ABSciex) using search algorithm Paragon 4.5.0.0, revision 1654 (ABSciex), and standard search settings to search against a database of all proteins of $M$. gallisepticum S6 (genbank id: AFFR01000000). The following parameters were used for this search: alkylation of cysteine by iodoacetamide, trypsin digestion, TripleTOF 5600 equipment, and a deep search with additional statistical analysis of results reliability. Specters were grouped with default settings by a ProGroup algorithm build-in to ProteinPilot. The statistical analysis of results reliability (and identification of threshold value of unused score) was carried out by a ProteomicS Performance Evaluation Pipeline Software (PSPEP) algorithm build-in to ProteinPilot.

The mass spectrometry proteomics data have been deposited to the ProteomeXchange Consortium (http:// proteomecentral.proteomexchange.org) via the PRIDE partner repository [44] with the dataset identifier PXD000249 and DOI 10.6019/PXD000249.

\section{Comparative analysis and in-silico reconstruction of DNA repair system}

We have used Gene Ontology database (http://www. geneontology.org/) and literature analysis, we compiled the list of all the genes involved in DNA repair in E. coli and (or) B. subtilis. For all of the selected genes we found homologues in the genome of $M$. gallisepticum using blastn and blastp algorithms (e-value <1e-25). We aligned selected proteins of $M$. gallisepticum with its respective homologues of $E$. coli and (or) B. subtilis in order to analyze the amino acid substitutions in the active center with the help of ClustalW2 algorithm (http:// www.ebi.ac.uk/Tools/msa/clustalw2/) and PDB database (http://www.rcsb.org/pdb/home/home.do). The results are shown in the Table 1 and the Additional file 4.

\section{Statistical analysis of mRNA expression levels by quantitative RT-PCR (qRT-PCR)}

Data presented are the average of three individual biological experiments with calculated standard deviation (Additional file 1); within each experiment, technical duplicates were performed. The level of each mRNA $(\log 2)$ identified in each condition was compared with the control, which was exponential growth phase for all conditions and stationary phase for stationary phase heat stress. To identify the significance of a mRNA level change, we used a t-test with multiple hypothesis testing correction by the Benjamini-Hochberg procedure [45].

\section{Identification of genes expression patterns during heat} stress

The Gene expression levels (log2) during 15 and $30 \mathrm{~min}$ heat stress were averaged. After that, a rank of each mRNA was calculated for control, $5 \mathrm{~min}$ and an average 15-30 min stress. The condition with the maximal expression gained a rank of " 1 ", and the condition with the minimal expression gained a rank of “ 3 ”.

\section{Additional files}

Additional file 1: Determination of culture growth rate.

Additional file 2: Synthetic oligonucleotides.

Additional file 3: The results of transcriptional profiling by qRTPCR. Data presented are the average of three individual experiments: within each experiment, technical duplicates were performed.

Additional file 4: DNA repair proteins of $M$. gallisepticum alignments with $E$. coli and (or) B. subtilis homologs.

Competing interests

The authors declare that they have no competing interests. 


\section{Authors' contributions}

AG designed the project, performed experimental and bioinformatics data and wrote the paper; GF designed the project, performed bioinformatics, qRT-PCR data and wrote the paper; MI performed qRT-PCR data and corrected the paper; DE performed functional protein domain search; PM performed bioinformatics and statistical calculations and wrote the paper; DA performed calculation for mass-spectrometry data and corrected the paper; OP performed protein extraction and sample preparation for chromato-mass-spectrometry; TG performed trypsinolysis for chromato-massspectrometry; SK performed mass-spectrometry data and wrote the paper; DK designed the project and wrote the paper, VG designed and supervised the project and wrote the paper. All authors read and approved the final manuscript.

\section{Acknowledgements}

This work was supported by a Grant (12-04-31696) from Russian Foundation for Basic Research (RFBR).

\section{Author details}

'Research Institute of Physico-Chemical Medicine, Malaya Pirogovskaya 1a, Moscow 119992, Russian Federation. ${ }^{2}$ Institute for Information Transmission Problems of the Russian Academy of Sciences, Bolshoy Karetny 19, Moscow 127994, Russian Federation. ${ }^{3}$ Moscow Institute of Physics and Technology, Institutsky 9, Dolgoprudny 141700, Russian Federation. ${ }^{4}$ ShemyakinOvchinnikov Institute of Bioorganic Chemistry of the Russian Academy of Sciences, Miklukho-Maklaya 16/10, Moscow 117997, Russian Federation.

Received: 25 June 2013 Accepted: 15 October 2013

Published: 23 October 2013

\section{References}

1. Lenhart JS, Schroeder JW, Walsh BW, Simmons LA: DNA repair and genome maintenance in Bacillus subtilis. Microbiol Mol Biol Rev 2012, 76:530-564.

2. Razin S, Yogev D, Naot Y: Molecular biology and pathogenicity of mycoplasmas. Microbiol Mol Biol Rev 1998, 62:1094-1156.

3. Alexeev D, Kostrjukova E, Aliper A, Popenko A, Bazaleev N, Tyakht A, Selezneva O, Akopian T, Prichodko E, Kondratov I, Chukin M, Demina I, Galyamina M, Kamashev D, Vanyushkina A, Ladygina V, Levitskii S, Lazarev V, Govorun V: Application of Spiroplasma melliferum proteogenomic profiling for the discovery of virulence factors and pathogenicity mechanisms in host-associated spiroplasmas. J Proteome Res 2012, 11:224-236.

4. Vanyushkina AA, Kamashev DE, Altukhov IA, Govorun VM: Identification of intracellular Spiroplasma melliferum metabolites by the HPLC-MS method. Biochemistry (Mosc) 2012, 77:864-877.

5. Iyer RR, Pluciennik A, Burdett V, Modrich PL: DNA mismatch repair: functions and mechanisms. Chem Rev 2006, 106:302-323.

6. Dalhus B, Laerdahl JK, Backe PH, Bjørås M: DNA base repair-recognition and initiation of catalysis. FEMS Microbiol Rev 2009, 33:1044-1078

7. Ischenko AA, Saparbaev MK: Alternative nucleotide incision repair pathway for oxidative DNA damage. Nature 2002, 415:183-187.

8. Dillingham MS, Kowalczykowski SC: RecBCD enzyme and the repair of double-stranded DNA breaks. Microbiol Mol Biol Rev 2008, 72:642-671. Table of Contents.

9. Janion C: Inducible SOS response system of DNA repair and mutagenesis in Escherichia coli. Int J Biol Sci 2008, 4:338-344.

10. Carvalho M, Fonseca MM, Scortecci C, Alfredo C, Blaha G, Agnez-lima LF: DNA repair in reduced genome: The Mycoplasma model. DNA Repair 2005, 360:111-119.

11. Schlacher K, Leslie K, Wyman C, Woodgate R: DNA polymerase V and RecA protein, a minimal mutasome. Mol Cell 2005, 17:561-572.

12. Foster PL: Stress-Induced Mutagenesis in Bacteria. Crit Rev Biochem 2007, 42(5):373-397.

13. Dörr T, Lewis K, Vulï̈ M: SOS response induces persistence to fluoroquinolones in Escherichia coli. PLoS Genet 2009, 5:e1000760.

14. Woese C: Bacterial evolution. Microbiol Rev 1987, 51(2):221-271.

15. Gruson D, Pereyre S, Renaudin H, Charron A, Be C: In Vitro Development of Resistance to Six and Four Fluoroquinolones in Mycoplasma pneumoniae and Mycoplasma hominis. Respectively 2005, 49:1190-1193.
16. Curti E, McDonald JP, Mead S, Woodgate R: DNA polymerase switching: effects on spontaneous mutagenesis in Escherichia coli. Mol Microbiol 2009, 71:315-331.

17. Kamashev D, Oberto J, Serebryakova M, Gorbachev A, Zhukova Y, Levitskii S, Mazur AK, Govorun V: Mycoplasma gallisepticum Produces a Histone-like Protein That Recognizes Base Mismatches in DNA. Biochemistry 2011, 50(40):8692-8702.

18. Levitskiy SA, Sycheva AM, Kharlampieva DD, Oberto J, Kamashev DE, Serebryakova MV, Moshkovskii SA, Lazarev VN, Govorun VM: Purification and functional analysis of recombinant Acholeplasma laidlawii histonelike HU protein. Biochimie 2011, 93:1102-1109.

19. Lage C, De Pádula M, De Alencar TAM, Gonçalves SRDF, Vidal LDS, Cabral-Neto J, Leitão AC: New insights on how nucleotide excision repair could remove DNA adducts induced by chemotherapeutic agents and psoralens plus UV-A (PUVA) in Escherichia coli cells. Mutation Research/ Reviews in Mutation Research 2003, 544:143-157.

20. Fisunov GY, Alexeev DG, Bazaleev NA, Ladygina VG, Galyamina MA, Kondratov IG, Zhukova NA, Serebryakova MV, Demina IA, Govorun VM: Core proteome of the minimal cell: comparative proteomics of three mollicute species. PLoS One 2011, 6:e21964.

21. Demina IA, Serebriakova MV, Ladygina VG, Galiamina MA, Zhukova NA, Alekseev DG, Fisunov Gl, Govorun VM: Comparative proteomic characteristic of Mycoplasmas (Mollycutes). Bioorg Khim 2011, 37:70-80.

22. Demina IA, Serebryakova MV, Ladygina VG, Rogova MA, Zgoda VG, Korzhenevskyi DA, Govorun VM: Proteome of the bacterium Mycoplasma gallisepticum. Biochemistry (Mosc) 2009, 74:165-174.

23. Graumann PL, Knust T: Dynamics of the bacterial SMC complex and SMClike proteins involved in DNA repair. Chromosome Res 2009, 17:265-275.

24. Wolff E, Kim M, Hu K, Yang H, Miller JH: Polymerases Leave Fingerprints: Analysis of the Mutational Spectrum in Escherichia coli rpoB To Assess the Role of Polymerase IV in Spontaneous Mutation. J Bacteriol 2004, 186:2004-2900.

25. Sciences ML: Review The bacterial LexA transcriptional repressor. Cell Mol Life Sci 2009, 66:82-93.

26. Savijoki K, Ingmer H, Frees D, Vogensen FK, Palva A, Varmanen P: Heat and DNA damage induction of the LexA-like regulator HdiR from Lactococcus lactis is mediated by RecA and ClpP. Mol Microbiol 2003, 50:609-621.

27. Cirz RT, O'Neill BM, Hammond JA, Head SR, Romesberg FE: Defining the Pseudomonas aeruginosa SOS response and its role in the global response to the antibiotic ciprofloxacin. J Bacteriol 2006, 188:7101-7110.

28. Robertson $A B$, Matson SW: Reconstitution of the very short patch repair pathway from Escherichia coli. J Biol Chem 2012, 287:32953-32966.

29. Razin A, Razin S: Methylated bases in mycoplasmal DNA. Nucleic Acids Res 1980, 8:1383-1390

30. Nur I, Szyf M, Razin A, Glaser G, Rottem S, Razin S: Procaryotic and eucaryotic traits of DNA methylation in spiroplasmas (mycoplasmas). J Bacteriol 1985, 164:19-24.

31. Lluch-Senar M, Luong K, Lloréns-Rico V, Delgado J, Fang G, Spittle K, Clark TA, Schadt E, Turner SW, Korlach J, Serrano L: Comprehensive Methylome Characterization of Mycoplasma genitalium and Mycoplasma pneumoniae at Single-Base Resolution. PLoS Genet 2013, 9:e1003191.

32. Wang D, Kreutzer DA, Essigmann JM: Mutagenicity and repair of oxidative DNA damage: insights from studies using defined lesions. Mutat Res 1998, 400:99-115.

33. Maier T, Schmidt A, Güell M: Quantification of mRNA and protein and integration with protein turnover in a bacterium. Mol Syst 2011, 7:1-12.

34. Güell M, Van Noort V, Yus E, Chen W-H, Leigh-Bell J, Michalodimitrakis K, Yamada T, Arumugam M, Doerks T, Kühner S, Rode M, Suyama M, Schmidt S, Gavin A-C, Bork P, Serrano L: Transcriptome complexity in a genomereduced bacterium. Science 2009, 326:1268-1271.

35. Mandelco L, Sechrest J, Lawrence TG, Van EJ, Weisburg WG, Tully JG, Rose DL, Petzel JP, Oyaizu H, Yang D: A Phylogenetic Analysis of the Mycoplasmas: Basis for Their Classification. J Bacteriol 1989, 171:6445-6467.

36. Sioud M, Boudabous A, Cekaite L: Transcriptional responses of Bacillus subtillis and thuringiensis to antibiotics and anti-tumour drugs. Int J Mol Med 2009, 23:33-39.

37. Au N, Kuester-schoeck E, Mandava V, Bothwell LE, Canny SP, Chachu K, Colavito SA, Fuller SN, Groban ES, Hensley LA, Brien TCO, Shah A, Tierney JT, Tomm LL, Gara TMO, Goranov Al, Grossman AD, Lovett CM: Genetic 
Composition of the Bacillus subtilis SOS System. J Bacterio/ 2005, 187:7655-7666.

38. Giuliodori AM, Gualerzi CO, Soto S, Vila J, Tavío MM: Review on bacterial stress topics. Ann N Y Acad Sci 2007, 1113:95-104.

39. Layton JC, Foster PL: Error-Prone DNA Polymerase IV Is Regulated by the Heat Shock Chaperone GroE in Escherichia coli. J Bacteriol 2005, 187:449-457.

40. Morowitz H, Maniloff J: Analysis of the life cycle of Mycoplasma gallisepticum. J Bacteriol 1966, 91:1638-1644.

41. Stewart CN, Via LE: A rapid CTAB DNA isolation technique useful for RAPD fingerprinting and other PCR applications. Biotechniques 1993, 14:748-750.

42. Hindson BJ, Ness KD, Masquelier DA, Belgrader P, Heredia NJ, Makarewicz AJ, Bright, et al: High-throughput droplet digital PCR system for absolute quantitation of DNA copy number. Anal Chem 2011, 83:8604-8610.

43. Laemmli UK: Cleavage of structural proteins during the assembly of the head of bacteriophage. Nature 1970, 15:680-685.

44. Vizcaíno JA, Côté RG, Csordas A, Dianes JA, Fabregat A, Foster JM, Griss J, Alpi E, Birim M, Contell J, O'Kelly G, Schoenegger A, Ovelleiro D, PérezRiverol Y, Reisinger F, Ríos D, Wang R, Hermjakob H: The PRoteomics IDEntifications (PRIDE) database and associated tools: status in 2013. Nucleic Acids Res 2013, 41(Database issue):D1063-D1069.

45. Benjamini Y, Hochberg Y: Controlling the False Discovery Rate: a Practical and Powerful Approach to Multiple Testing. J R Stat Soc 1995, 57:289-300.

doi:10.1186/1471-2164-14-726

Cite this article as: Gorbachev et al:: DNA repair in Mycoplasma gallisepticum. BMC Genomics 2013 14:726.

\section{Submit your next manuscript to BioMed Central and take full advantage of:}

- Convenient online submission

- Thorough peer review

- No space constraints or color figure charges

- Immediate publication on acceptance

- Inclusion in PubMed, CAS, Scopus and Google Scholar

- Research which is freely available for redistribution

Submit your manuscript at www.biomedcentral.com/submit
C Biomed Central 